\title{
Bio Concrete- The Self-Healing Concrete
}

\author{
Jasira Bashir, IfrahKathwari, Aditya Tiwary and KhushpreetSingh
}

Department of Civil Engineering, Chandigarh University, National Highway 95, Chandigarh-Ludhiana Highway, Mohali-140413,Punjab, India; jasirabashir@gmail.com, ifrahkathwari@gmail.com, adadtiwary15@gmail.com,

khushpreet85@yahoo.com

\begin{abstract}
Background/Objectives: In the present scenario the use of bio concrete proved very fruitful for construction of durable structures and it also improved the properties of concrete and maintenance cost is reduced. Method/Statistical Analysis: In this paper an attempt has been made to use different microorganisms so as to observe the strength gain as a result of sprouting of filler material inside the cement sand matrix pores. The strength of concrete mix is evaluated by conducting compressive strength test, split tensile strength test and flexural strength test. Scanning Electron Microscopy(SEM)/XRay Diffraction(XRD) analysis is further done to prove involvement of the isolated ureolytic bacteria in calcium carbonate precipitation.Findings: From the tests conducted on various specimens of bio concrete using different bacteria, a clear comparison can be made for strengths of different specimens of bio concrete using different bacteria and convention concrete. The results obtained from the experiment concludes that when water enter in the concrete after the formation of cracks activates the dormant bacteria (inactive) by the process of metabolically mediated calcium carbonate precipitation and it increased the strength of bio concrete as compared to the conventional concrete.Applications/Improvements: Bio concrete is durable and offers better resistance to corrosion and freeze thaw. Crack remediation using bio-concrete is better than epoxy treatments.
\end{abstract}

Keywords: Bio-concrete, Bacteria, Compressive Strength, Flexural Strength Test, MICCP, Split Tensile Strength

\section{Introduction}

Concrete is an important and extensively used building material used for construction works. It is mainly used in heavy constructions because of its strength and durability. No matter how carefully the concrete is mixed or reinforced it eventually ends up in cracking at some point. There are many factors that affect the durability and strength of concrete, one of the most common hindrances is crack formation. Large cracks may affect the structural integrity while the small cracks reduce the durability of the structure. Cracks also increase the permeability of matrix thereby increasing the chances of corrosion in reinforcement. Therefore, the sole cause of structural failure is cracking. In order to reduce the chances of crack formation a structure requires regular maintenance which can be costly and may further increase the maintenance cost of the structure. One way to reduce such costs and to increase the durability of structure is to use a concrete that has self-healing mechanism. This technique is based on bio mineralization of bacteria in concrete, a biological process commonly seen in few forms of microorganisms. The strength and durability can be increased by using these microorganisms as binders and fillers in concrete. Epoxy treatment is currently used for the repair works which is harmful to the environment and health as toxic fumes and gases evolved may cause serious skin and breathing issues. Hence the use of biological techniques should be focused. The use of biological techniques in concrete lead to the invention of a new building material i.e. bio-concrete.

\subsection{Bio Concrete-The Living Concrete}

Bio concrete is an example of linking nature with construction. The bio concrete or the living concrete is mixed in the same way as that of regular concrete but the extra ingredient i.e. the healing agent is added. This

${ }^{*}$ Author for correspondence 
agent remain intact while mixing and placing, it becomes active only when it comes in contact with water if the concrete cracks. The healing agents can remain dormant in concrete for about 200 years ${ }^{1}$. Bio concrete produces limestone $\left(\mathrm{CaCO}_{3}\right)$ crystals to fill up the cracks appearing on the surfaces. When the cracks begin to form in the concrete structure water enters the cracks ${ }^{2}$. After coming in contact with water and oxygen, the inactive bacteria become active. They multiply and germinate in the calcium based nutrient (calcium lactate), while feeding on the lactate they combine calcium with carbonate ions to form limestone or calcite which seals the cracks. Bio concrete mimes the principle involved in healing of bones fractures in humans naturally by mineralization caused by osteoblast cells. The oxygen consumption not only helps in bacterial conversion of calcium lactate to limestone but also helps in reducing the oxygen content in concrete which creates a medium for corrosion. Due to bacterial conversion, the oxygen gets consumed thereby increasing the durability of steel reinforcement.

\subsection{Bacteria Used in Bio Concrete}

In suspension state, concrete mix is added with bacteria. Concrete being extremely alkaline in nature, the bacteria added should fit in some special norms. The added bacteria should be able to withstand the harsh environmental conditions of concrete. Concrete is a dry material and the $\mathrm{pH}$ value of cement and water when mixed is up to 13 which makes it confrontational as most of the organisms cannot survive in an environment having $\mathrm{pH}$ value higher than 10 .

\subsubsection{Types of Bacteria}

Bacteria naturally occur in nature in various forms. They are present not only on the surface but also beneath the surface of the earth. The various bacteria that can be used in concrete are:

\subsubsection{Anaerobic Bacteria}

If anaerobic bacteria like closely related specie of shewanella are added to concrete, the compressive strength increases from $25-30 \%$.

\subsubsection{Aerobic Bacteria ${ }^{4}$}

The various types of aerobic bacteria that can be used in concrete are:

- Bacillus pasteurii
- Bacillus sphaericus

- Escherichia coli

- Bacillus subtilis

- Bacillus cohnii

- Bacillus pseudofirmus

- Bacillus halodurans

- Bacillus massiliensis

It has been observed after 7 days strength the s.soli and L. fusiformis showed better compressive strength while as B. massiliensis and A. crystallopoietes no strength improvement was observed. A.crystallopoietes showed the maximum strength after 28 days ${ }^{\underline{5}}$.

\section{Method of Using Self-Healing Bacteria}

The method of using microbes in bacterial concrete is known as microbial Induced Calcium Carbonate Precipitation (MICCP) or bio mineralization ${ }^{6}$. Bio mineralization is a biological precipitation in which organisms create a local micro environment by providing chemical precipitation of mineral phases extracellularly. Some usually occurring metabolic processes including sulfate reduction, photosynthesis and urea hydrolysis end up in giving $\mathrm{CaCO}_{3}$ as there byproduct ${ }^{\underline{T}}$. Various bacteria can precipitate calcium carbonate in both natural and laboratory conditions. Calcium carbonate precipitation is mainly governed by following factors ${ }^{8}$

- $\mathrm{pH}$ value.

- Calcium concentration.

- DIC (Dissolved Inorganic Carbon) concentration.

- Nucleation sites.

The main mechanism behind making a self-healing concrete is that the bacteria should be able to convert the soluble organic nutrients into insoluble inorganic calcite crystals which seals the cracks. The self-healing agent that is applied to the concrete consists of two components, bacteria which acts as a catalyst and calcium lactate i.e. the mineral precursor which is converted to calcium carbonate minerals? ${ }^{2}$. The presence of $\mathrm{CO}_{2}$ and calcium hydroxide within the concretion of calcium carbonate in control concrete as shown in the reaction given below:

$$
\mathrm{CO}_{2}+\mathrm{Ca}(\mathrm{OH})_{2} \rightarrow \mathrm{CaCO}_{3}+\mathrm{H}_{2} \mathrm{O}
$$

The calcium carbonate is formed due to the presence of limited $\mathrm{CO}_{2}$ Calcium hydroxide being soluble in nature dissolves in excess water and comes out from cracks as 
leaching. In self-healing concrete active metabolic conversion of calcium nutrients takes place due to the presence of bacteria ${ }^{10}$.

$$
\mathrm{Ca}\left(\mathrm{C}_{3} \mathrm{H}_{5} \mathrm{O}_{2}\right)_{2}+7 \mathrm{O}_{2} \rightarrow \mathrm{CaCO}_{3}+5 \mathrm{CO}_{2}+5 \mathrm{H}_{2} \mathrm{O}
$$

There are two pathways of calcium precipitation done by microorganisms:

- It involves Sulphur cycle in which Sulphur reducing bacteria carry out Sulphur reduction in anoxic environment.

- It involves nitrogen cycle, explicitly the amino acid oxidative deamination and urea or uric acid degradation using ureolytic bacteria in aerobic environment and in anaerobic conditions nitrate reductions.

One of the most commonly used methods applied for MICCP is hydrolysis of urea through the urease enzyme in an environment in which calcium is in abundance. This method results in the hike in the dissolved carbon (inorganic) concentration and $\mathrm{pH}$. Urease propels the hydrolysis of urea in bacterial environment to ammonia and $\mathrm{CO}_{2}$, resulting in $\mathrm{pH}$ and carbonate concentration increase. $1 \mathrm{~mol}$ of urea forms $1 \mathrm{~mol}$ of ammonia and 1 mol of carbonate by intracellular hydrolization, which in turn forms additional $1 \mathrm{~mol}$ of ammonia and carbonic acid spontaneously as follows:

$$
\begin{gathered}
\mathrm{CO}\left(\mathrm{NH}_{2}\right)_{2}+\mathrm{H}_{2} \mathrm{O} \rightarrow \mathrm{NH}_{2} \mathrm{COOH}+\mathrm{NH}_{3} \\
\mathrm{NH}_{2} \mathrm{COOH}+\mathrm{H}_{2} \mathrm{O} \rightarrow \mathrm{NH}_{3} \mathrm{H}_{2} \mathrm{CO}_{3}
\end{gathered}
$$

A state of equilibrium in is attained to form bicarbonate in water, $\mathrm{pH}$ rises due to $1 \mathrm{~mol}$ of ammonium and hydroxide ions ${ }^{11}$.

$$
\begin{gathered}
\mathrm{H}_{2} \mathrm{CO}_{3} \rightarrow 2 \mathrm{H}^{+}+2 \mathrm{CO}_{3}^{2-} \\
\mathrm{NH}_{3}+\mathrm{H}_{2} \mathrm{O} \rightarrow \mathrm{NH}^{4-}+\mathrm{OH}^{-} \\
\mathrm{Ca}^{2-}+\mathrm{CO}^{3-} \rightarrow \mathrm{CaCO}_{3}
\end{gathered}
$$

Observations depict that in calcium precipitation a key role is being played by surfaces of bacteria due to the involvement of negatively charged ions and neutral $\mathrm{pH}$, the metal ions with positive charge can combine with bacterial surfaces thereby encouraging heterogeneous nucleation. The possible biochemical reaction can be summed up as:

$$
\begin{gathered}
\mathrm{Ca}^{2+}+\text { Cell } \rightarrow \text { Cell-Ca }{ }^{2+} \\
\mathrm{Cl}^{-}+\mathrm{HCO}_{3-}+\mathrm{NH}_{3} \rightarrow \mathrm{NH}_{4} \mathrm{Cl}+\mathrm{CO}_{3}^{2-}
\end{gathered}
$$

\subsection{SEM/EDX and XRD Analysis}

- SEMreveals the direct involvement of the isolated ureolytic bacteria in calcium carbonate precipitation and the production of calcite was confirmed by XRD and Energy-Dispersive X-Ray Analysis (EDX) ${ }^{12}$.

- In EDX analysis, the spectra of $\mathrm{CaO}$ and $\mathrm{CaCO}_{3}$ were noted for all the mixtures for 28 days. It was observed that the spectra of $\mathrm{CaO}$ decreased while the spectra of $\mathrm{CaCO}_{3}$ increased after 28 days. The concrete specimen without bacteria was also analyzed and it was observed that it showed minor or no signs of $\mathrm{CaCO}_{3}$ crystals. Hence it was concluded that $\mathrm{CaCO}_{3}$ spectra increased due to the presence of bacteria.

- XRD was done for microstructure analysis in order to confirm the presence of calcite in the form of $\mathrm{CaCO}_{3}$ at the age of 28 days $\frac{13}{}$.

\subsection{Advantages and Disadvantages of Bio Concrete}

\subsubsection{Advantages ${ }^{14}$}

- The use of bio concrete significantly influences the strength of concrete.

- It has lower permeability than conventional concrete.

- It offers great resistance to freeze-thaw attacks.

- The chances of corrosion in reinforcement are reduced.

- Remedying of cracks can be done efficiently.

- Maintenance cost of this concrete is low.

\subsubsection{Disadvantages}

- Design of bacterial concrete is not mentioned in IS codes or any other codes.

- Cost of this concrete is comparatively higher than conventional concrete i.e. about $7-28 \%$ more than conventional concrete.

- The sprouting of bacteria is not suitable in any environment.

- The investigations involved in calcite precipitation are costly.

- Bacteria that grow in concrete are not good for human health and atmosphere and hence its usage should be limited to the structure.

\subsection{Benefits it Can Serve in India}

The climate of India is diverse from region to region because of its topography. It observes a wide range of 
temperature changes from mountains, plains, forests, to beaches. Many cities such as New Delhi, Lucknow, Patna, Varanasi etc. observe drastic temperature changes from very warm climate in April to mid-June to very cold climate between November and February. Extreme climates can deteriorate the concrete surfaces and which may ultimately result in failure of structure. Bio concrete can be used as the best alternative for constructions in extreme climates. As India is a developing country, impressive infrastructure plays an important role so bio concrete can be used in the construction of crack resistant and durable high rise buildings and underground constructions. Apart from this bio concrete can be used for constructing structures meant for irrigation.

\section{Results and Discussions}

The test results of bio concrete and conventional concrete showed an eloquent difference. The table and charts given shows the clear information regarding compressive strength, split tensile strength and flexural strength of M20

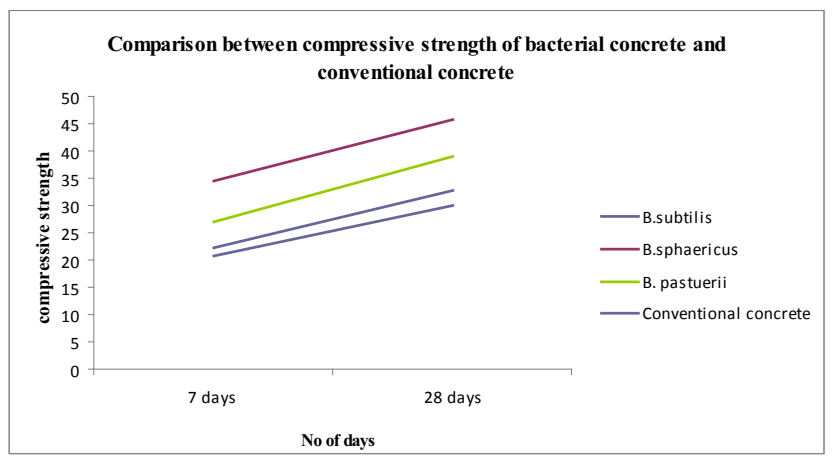

Figure 1. Comparison between compressive strength of bacterial concrete and conventional concrete.

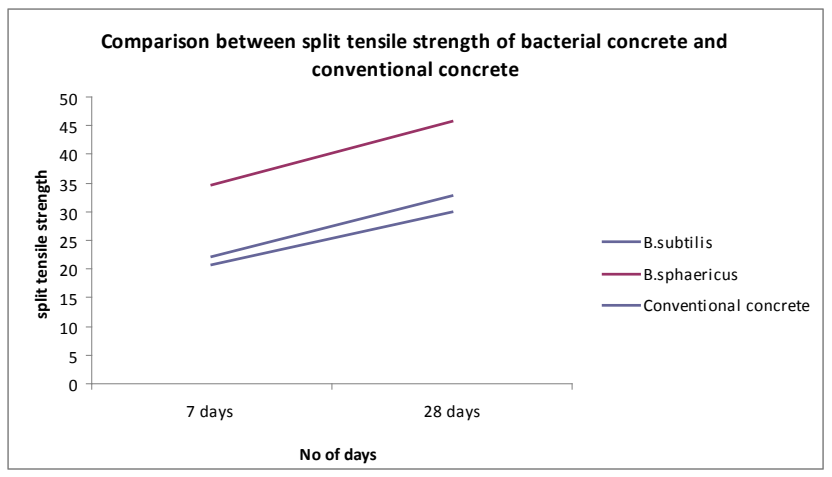

Figure 2. Comparison between split tensile strength of bacterial concrete and conventional concrete. conventional concrete and M20 bio concrete using different types of bacteria ${ }^{15}$. The results of compressive strength of bacterial concrete and conventional concrete are given in Table 1 and Figure 1. The results of split tensile strength of bacterial concrete and conventional concrete are given in Table 2 and Figure 2. The results of flexural strength of bacterial concrete and conventional concrete are given in Table 3 and Figure 3.

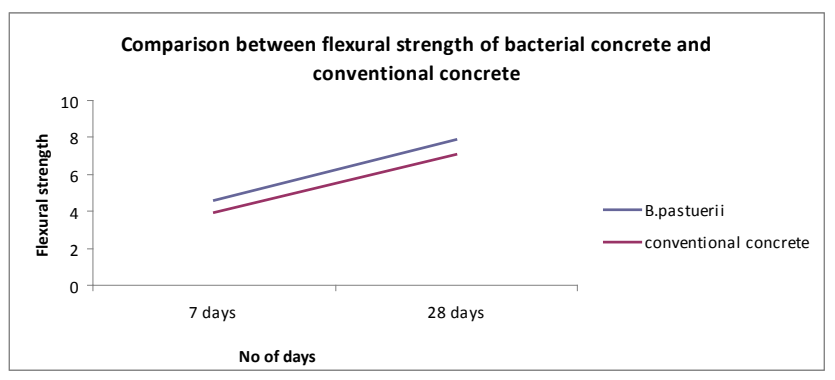

Figure 3. Comparison between flexural strength of bacterial concrete and conventional concrete.

Table 1. Comparison between compressive strength of bacterial concrete and conventional concrete

\begin{tabular}{|c|c|c|c|c|c|}
\hline \multirow{3}{*}{ S.No } & \multicolumn{3}{|c|}{ Bacterial concrete } & \multicolumn{2}{|c|}{$\begin{array}{l}\text { Conventional } \\
\text { concrete }\end{array}$} \\
\hline & \multicolumn{3}{|c|}{$\begin{array}{l}\text { Compressive strength } \\
\qquad\left(\mathrm{N} / \mathrm{mm}^{2}\right)\end{array}$} & \multicolumn{2}{|c|}{$\begin{array}{c}\text { Compressive } \\
\text { strength }\left(\mathrm{N} / \mathrm{mm}^{2}\right)\end{array}$} \\
\hline & $\begin{array}{l}\text { Name of } \\
\text { bacteria }\end{array}$ & 7 days & $\begin{array}{c}28 \\
\text { days }\end{array}$ & 7 days & 28 days \\
\hline 1 & $\begin{array}{l}\text { Bacillus } \\
\text { Subtilis }\end{array}$ & 22.18 & 32.74 & 20.84 & 29.99 \\
\hline 2 & $\begin{array}{l}\text { Bacillus } \\
\text { sphaericus }\end{array}$ & 34.58 & 45.72 & 20.84 & 29.99 \\
\hline 3 & $\begin{array}{l}\text { Bacillus } \\
\text { pasteurii }\end{array}$ & 27.09 & 38.98 & 20.84 & 29.99 \\
\hline
\end{tabular}

Table 2. Comparison between split tensile strength of bacterial concrete and conventional concrete

\begin{tabular}{|c|c|c|c|c|c|}
\hline \multirow{2}{*}{ S.No } & \multicolumn{2}{|c|}{ Bacterial concrete } & \multicolumn{2}{c|}{$\begin{array}{c}\text { Conventional } \\
\text { concrete }\end{array}$} \\
\cline { 2 - 6 } & \multicolumn{2}{|c|}{$\begin{array}{c}\text { Split tensile strength } \\
\left(\mathrm{N} / \mathrm{mm}^{2}\right)\end{array}$} & \multicolumn{2}{|c|}{$\begin{array}{c}\text { Split tensile strength } \\
\left(\mathrm{N} / \mathrm{mm}^{2}\right)\end{array}$} \\
\cline { 2 - 6 } & $\begin{array}{c}\text { Name of } \\
\text { bacteria }\end{array}$ & $\begin{array}{c}7 \\
\text { days }\end{array}$ & $\begin{array}{c}28 \\
\text { days }\end{array}$ & 7 days & 28 days \\
\hline 1 & $\begin{array}{c}\text { Bacillus } \\
\text { Subtilis }\end{array}$ & 2.36 & 3.73 & 1.708 & 3.26 \\
\hline 2 & $\begin{array}{c}\text { Bacillus } \\
\text { sphaericus }\end{array}$ & 2.24 & 3.35 & 1.708 & 3.26 \\
\hline
\end{tabular}


Table 3. Comparison between flexural strength of bacterial concrete and conventional concrete

\begin{tabular}{|c|c|c|c|c|c|}
\hline \multirow{2}{*}{ S.No } & \multicolumn{2}{|c|}{ Bacterial concrete } & \multicolumn{2}{c|}{\begin{tabular}{c} 
Conventional concrete \\
\cline { 2 - 6 }
\end{tabular}} & \multicolumn{2}{|c|}{$\begin{array}{c}\text { Flexural strength }(\mathrm{N} / \\
\left.\mathbf{m m}^{2}\right)\end{array}$} & \multicolumn{2}{|c|}{$\begin{array}{c}\text { Flexural strength } \\
\left(\mathrm{N} / \mathbf{m m}^{2}\right)\end{array}$} \\
\cline { 2 - 6 } & $\begin{array}{c}\text { Name of } \\
\text { bacteria }\end{array}$ & $\begin{array}{c}7 \\
\text { days }\end{array}$ & $\begin{array}{c}\mathbf{2 8} \\
\text { days }\end{array}$ & 7 days & $\mathbf{2 8}$ days \\
\hline 1 & $\begin{array}{c}\text { Bacillus } \\
\text { pasteurii }\end{array}$ & 4.6 & 7.85 & 3.92 & 7.06 \\
\hline
\end{tabular}

\section{Conclusion}

The conclusion can be summarized as:

- The compressive, split tensile and flexural strength of M20 bio-concrete is found to be higher than M2O conventional concrete.

- The percentage increase in compressive strength of bio concrete using B. Subtilisfor 7 days is $6.42 \%$ and for 28 days is $9.16 \%$ higher than conventional concrete.

- The percentage increase in compressive strength of bio concrete using B. Sphaericusfor 7 days is $65.93 \%$ and for 28 days is $52.42 \%$ higher than conventional concrete.

- The percentage increase in compressive strength of bio concrete using B. pasteurii for 7 days is $29.99 \%$ and for 28 days is $29.97 \%$ higher than conventional concrete.

- The percentage increase in split tensile strength of bio concrete using B. subtilis for 7 days is $38.17 \%$.and for 28 days is $14.41 \%$ higher than conventional concrete.

- The percentage increase in split tensile strength of bio concrete using B. sphaericusfor 7 days is $31.14 \%$.and for 28 days is $2.76 \%$ higher than conventional concrete.

- The percentage increase in flexural strength of bio concrete using B. pasteurii for 7 days is $17.34 \%$ and for 28 days is $11.18 \%$ higher than conventional concrete.

- It reduces the chances of various defects that can take place in a structure like corrosion of reinforcement and cracks.

- Bacteria can further be used in mortar and bricks to improve their properties.

- Crack remediation using bio-concrete is better than epoxy treatments.

\section{References}

1. Rao SMV, Reddy VS, Hafsa M, Veena P, Anusha P. Bioengineered concrete - a sustainable self-healing construction material. Research Journal of Engineering Sciences. 2013 June; 2(6):46-7.
2. Ramachandran SK, Ramakrishnan V, Bang SS. Remediation of concrete using microorganisms. ACI Materials Journal. 2001 Jan; 98(M1):3-9.

3. Mohanadoss P, Amirreza T, Rosli MZ, Ismail M, Majid MZA, Ali K, Hesam K. Bio concrete strength, durability, permeability, recycling and effects on human health: a review. Proceedings of the Third International Conference Advances in Civil, Structural and Mechanical Engineering. CSM 2015 Copyright (C) Institute of Research Engineers and Doctors, USA; 2015. p. 1-2. DOI: 10.15224/ 978-1-63248062-0-28.

4. Soundharya S, Nirmal KK. Strength improvement studies on self-healing characteristics of bacterial concrete. International Journal of Engineering Science Invention Research and Development. 2014 Oct; I(IV):162-4.

5. Navneet C, Anita R, Rafat S. Calcium carbonate precipitation by different bacterial strains. African Journal of Bio Technology. 2011 Aug; 10(42):8359-72.

6. Kavia K, Hema C. Dressing of structural cracks using Bio Concrete. Indian Journal of Science and Technology. 2015 Nov; 8(32):1-4.

7. Vekariya M, Jayesh K, Pitroda. Bacterial concrete: new era for construction industry. International Journal of Engineering Trends and Technology. 2013 Sep; 4(9):4129-33.

8. Jonkers HM. Self-healing concrete: A biological approach, in self-healing materials. Springer. 2011; 56:1-12.

9. Henk MJ, Schlangen E. Development of a bacteria-based self-healing concrete. Taylor and Francis Group, London; 2008. p. 425-30.

10. Jonkers HM, Schlangen E. A two component bacteria-based self-healing concrete. Concrete Repair, Rehabilitation and Retrofitting II. Taylor \& Francis Group, London; 2009. p. 213-6.

11. Noraisyah N, Leong SW, Praveen R. A Review on the compressive strength of bio mineralized mortar. In the 3rd National Graduate Conference (NatGrad2015), University Tenaga Nasional, Putrajaya Campus; 2015 Apr 8-9. p. 235-6.

12. Manikandan AT, Padmavathi A. An experimental investigation on improvement of concrete serviceability by using bacterial mineral precipitation. International Journal of Research and Scientific Innovation (IJRSI). 2015 Mar; 2(3):48.

13. Maheswaran S, Dasuru SS, Murthy ARC, Bhuvaneshwari B, Kumar VR, Palani GS, Iyer NR, Sarayu KM, Sandhya S. Strength improvement studies using new type wild strain Bacillus cereus on cement mortar. Current Science. 2014 Jan; 106(1):50.

14. Beena K. Microbial concrete: a multi-purpose building material-an overview. International Journal of Advances in Engineering and Technology. 2015 Jan; 7(6):1608-19.

15. Sunil SPR, Rao MVS, Aparna P, Ch S. Performance of ordinary grade bacterial concrete. International Journal of Earth Sciences and Engineering. 2010 Feb; 3(1):116-24. 